\title{
NALAZ SLAVONSKIH BANSKIH I UGARSKIH \\ DENARA IZ GROBA 241 S LOKALITETA \\ TORČEC-CIRKVIŠĆE
}

THE FIND OF SLAVONIAN DENARII BANALES

AND HUNGARIAN DENARS IN GRAVE 241 AT THE SITE OF TORČEC-CIRKVIŠĆE

\author{
Siniša Krznar \\ Institut za arheologiju \\ Jurjevska 15 \\ HR - 10000 Zagreb \\ sinisa.krznar@iarh.hr \\ Luka Štefan \\ Podbrežje XII. a 18 \\ HR - 10020 Zagreb \\ Istefan.archaeology@gmail.com
}

\author{
Siniša Krznar \\ Institute of Archaeology \\ Jurjevska 15 \\ HR - 10000 Zagreb \\ sinisa.krznar@iarh.hr \\ Luka Štefan \\ Podbrežje XII. a 18 \\ HR - 10020 Zagreb \\ Istefan.archaeology@gmail.com
}

UDK / UDC: 904:737.1(497.525 Torčec)"653"

Izvorni znanstveni rad/Original scientific paper

https://doi.org/10.52064/vamz.54.1.32

U radu se analizira i interpretira nalaz srednjovjekovnoga srebrnog novca pronađenog tijekom arheoloških istraživanja 2014 godine u grobu 241. Riječ je o 15 primjeraka banskih denara kovanih u vrijeme kraljeva Bele IV., Stjepana V. i Ladislava IV. te šest primjeraka ugarskih denara Stjepana $V$. Novac je pronađen na području zdjeličnog pojasa pokojnika starosti 30 - 35 godina $i$ najvjerojatnije se nalazio u vrećici od organskog materijala. $\mathrm{Na}$ temelju ovih nalaza i stratigrafskih odnosa s drugim grobovima ukop ovog pokojnika može se datirati u posljednju četvrtinu 13. stoljeća.

Ključne riječi:

Podravina, Torčec, srednji vijek, groblje, novac, denari, numizmatika

Uvod

Brojnim rekognosciranjima i arheološkim istraživanjima u okolici Torčeca, danas maloga podravskog mjesta (sl. 1), ustanovIjen je velik broj srednjovjekovnih lokaliteta. Uglavnom, riječ je o lokalitetima naseobinskog karaktera koji nam ukazuju na visok intenzitet života i naseljavanja tog prostora tijekom srednjeg vijeka. ${ }^{1}$ Položaj Torčec-Cirkvišče ističe se već samim svojim
This paper analyses and interprets the find of medieval silver coins discovered in grave 241 during archaeological excava tions in 2014. This was denarius banalis coins minted during the reigns of kings Béla IV, Stephen V and Ladislaus IV, and six examples of Hungarian denars minted during the reign of King Stephen $V$. The coins were discovered in the pelvic-girdle region of a deceased male between 30 and 35 years old and were proba bly placed in a bag made of organic material. On the basis of this find and stratigraphic relations with other graves, this individual's burial can be dated to the last quarter of the $13^{\text {th }}$ century.

Key words:

Podravina, Torčec, the Middle Ages, cemetery, coins, denars, numismatics

\section{Introduction}

Numerous field surveys and archaeological excavations around Torčec, today a small village in Podravina (Fig. 1), have discovered a large number of medieval archaeological sites. These were mostly settlements, pointing to the high intensity of life and habitation in that area during the Middle Ages. ${ }^{1}$ The site of Torčec-Cirkvišče distinguishes itself from others in its toponym, 


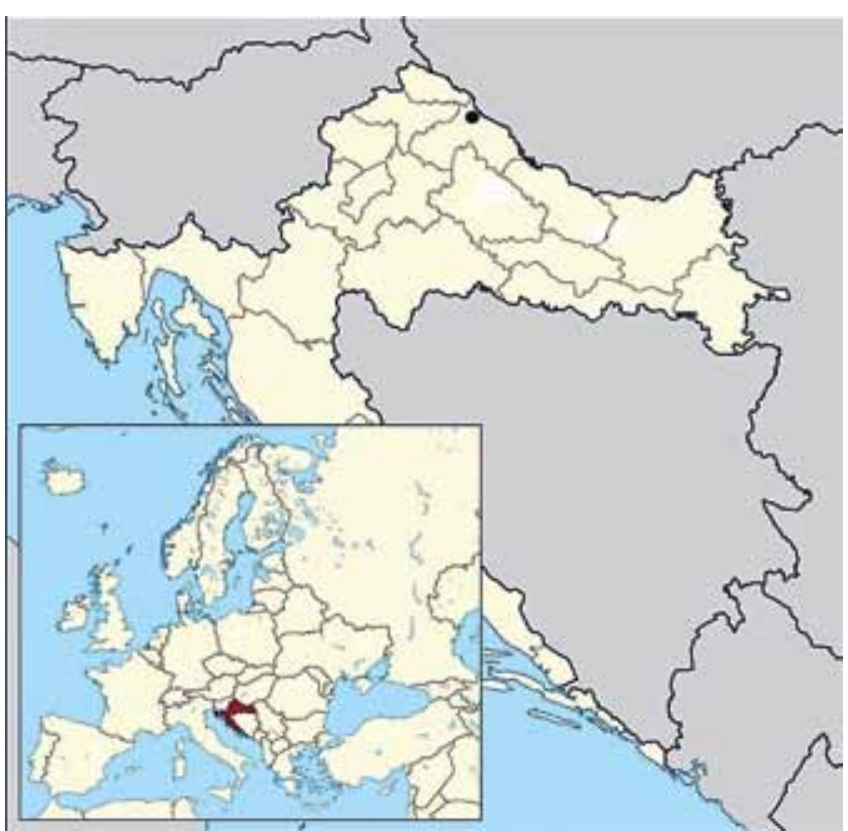

SLIKA 1. Položaj lokaliteta Torčec-Cirkvišče (izradio S. Krznar). FIGURE 1. Location of the Torčec-Cirkvišče site (made by S. Krznar)
SLIKA 3. Crtež groba 241 s položajem nalaza novca (izradila K. Turkalj). FIGURE 3. Drawing of grave 241 with the position of the coins (made by K. Turkalj).

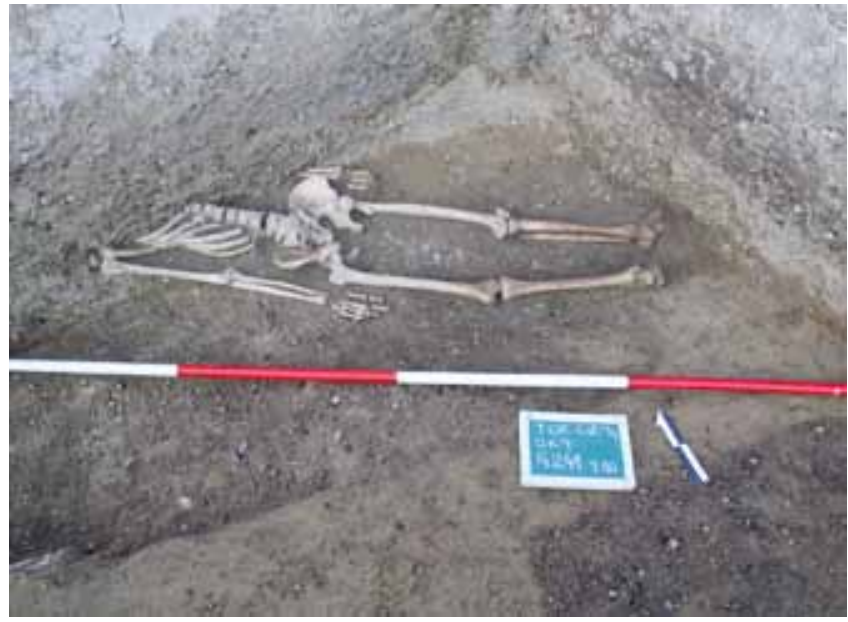

SLIKA 2. Grob 241 s lokaliteta Torčec-Cirkvišče (snimila K. Turkalj). FIGURE 2. Grave 241 at the site of Torčec-Cirkvišče (photo by K. Turkalj).

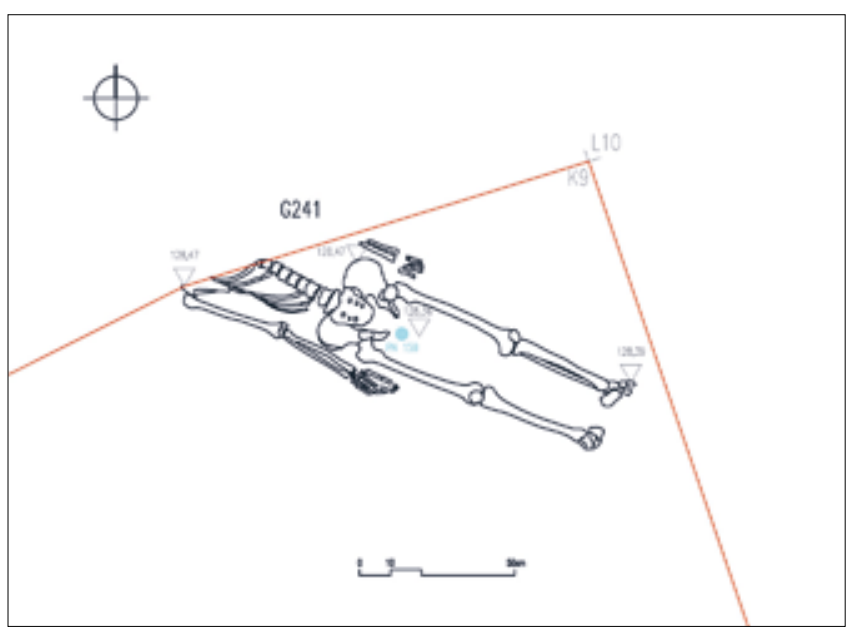

pointing to a sacred function for this site. This was confirmed by trial excavation conducted in $2002{ }^{2}$ during which a cemetery was discovered at the site and elements for location of the Church of St Stephen the King were acquired. The church was mentioned in the Diocese of Zagreb's list of parishes as ...sancti Stephanis regis circa Drauam... ${ }^{3}$ The excavation of the site was resumed in 2009 and continued until 2016, except in the year 2010. Altogether 453 graves were discovered, as well as very sparse remains of a church that functioned from the mid- $15^{\text {th }}$ century to the mid-1 $7^{\text {th }}$. Traces of an earlier structure, and also a later one, mentioned in sources, were not discovered. The earliest grave discovered was dated to the end of the eighth cen-
2 Istraživanja je u razdoblju od 31. srpnja do 10. kolovoza 2002. godine proveo Institut za arheologiju iz Zagreba u suradnji s Gradskim muzejem Koprivnica, pod vodstvom dr. sc. Tajane Sekelj Ivančan.

3 Buturac 1984, 75-76; Sekelj Ivančan, Tkalčec 2003; Sekelj Ivančan 2008, 98.

$4 \quad$ Krznar 2013, 68.
Excavation from July 31 to August 10, 2002 was conducted by the Institute of Archaeology, Zagreb, in cooperation with the Koprivnica Town Museum. The excavation was led by Tajana Sekelj Ivančan, PhD

3 Buturac 1984, 75-76; Sekelj Ivančan, Tkalčec 2003; Sekelj Ivančan 2008, 98

$4 \quad$ Krznar 2013, 68 


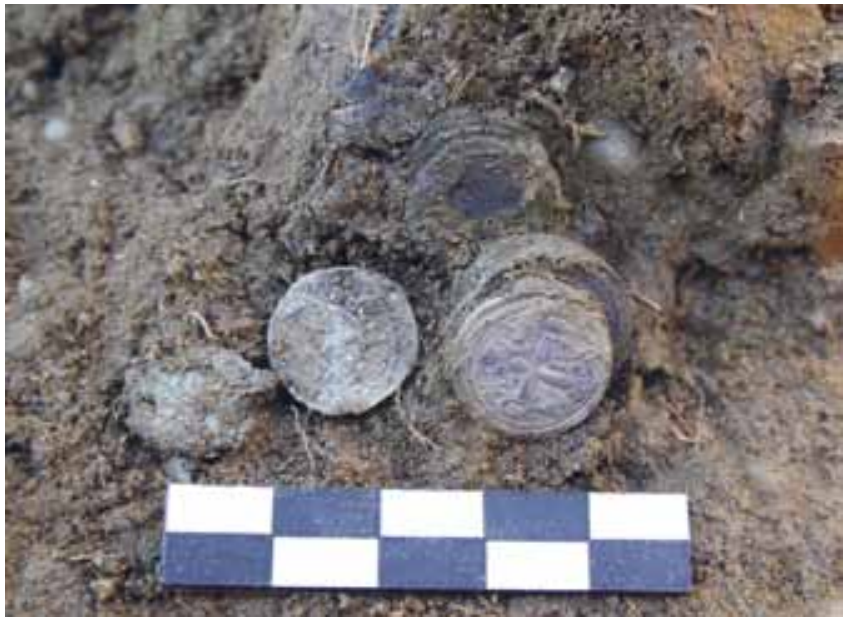

SLIKA 4. Nalaz novca in situ (snimio S. Krznar). FIGURE 4. Find of coins in situ (photo by S. Krznar).

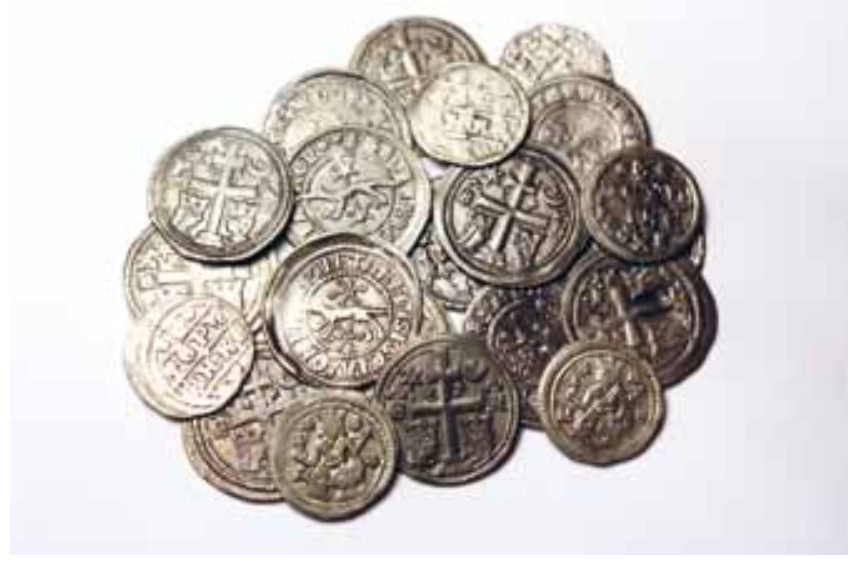

SLIKA 5. Novac iz groba 241 (snimio S. Krznar). FIGURE 5. Coins from grave 241 (photo by S. Krznar). grobovi mogu se datirati od druge polovice 12 . do početka 18. stoljeća, odnosno do 1731. - 1733. godine, kada se već spominje nova crkva u samom središtu Torčeca. ${ }^{5}$ Nalazi pronađeni u grobovima karakteristični su za period razvijenog i kasnoga srednjeg i ranoga novog vijeka. Uglavnom, riječ je o dijelovima nošnje i nakitu, a u mlađem razdoblju i predmetima osobne pobožnosti. Pojedini nalazi ipak odskaču od te uobičajene slike. Takav je i skupni nalaz srebrnog novca pronađen u grbu 241. Navedeni je grob istražen tijekom kampanje 2014. godine u sjeveroistočnom uglu sonde. Nalazi se u superpoziciji nad starijim grobovima G 240 i G 243. Pokojnik iz groba 240 datiran je ${ }^{14} \mathrm{C}$ metodom u drugu polovicu 12., odnosno prvu polovicu 13. stoljeća. ${ }^{6}$ Prilikom istraživanja ustanovljeno je da dio groba 241 izlazi iz okvira sonde te lubanja i lijevi dio trupa nisu istraženi (sl. 2).

U grobu je pokopan muškarac u trenutku smrti u dobi između 30 i 35 godina. Između njegovih nogu, u visini zdjeličnih kostiju, pronađen je skupni nalaz srebrnog novca koji se najvjerojatnije nalazio u vrećici od organskog materijala (sl. 3, 4). Pronađen je 21 primjerak srebrnog novca (sl. 5). Većina se može determinirati kao banski denari (15 komada) kovani u vrijeme kraljeva Bele IV., Stjepana V. i Ladislava IV. Riječ je o najvećem broju banskih denara pronađenih u jednom grobu na prostoru Hrvatske. Osim njih, pronađeno je šest denara kovanih za kralja Stjepana v. Zahvaljujući ovom nalazu, pokojnika, u čijem su grobu pronađeni, možemo svrstati u viši socijalni stalež torčanske zajednice. Takvu konstataciju, međutim, ne potvrđuje antropološka analiza provedena na skeletu. Tragovi teškoga fizičkog rada tury or the beginning of the ninth. ${ }^{4}$ The rest of the graves can be dated to the period from the second half of the $12^{\text {th }}$ century to the beginning of the $18^{\text {th }}$, or to $1731-1733$, when a new church in the very centre of Torčec had already been mentioned. ${ }^{5}$ Finds discovered in graves are characteristic of the period of the High and late Middle Ages and the early modern period. They are mostly parts of the costume and jewellery, and, in later periods, items of personal piety. Certain finds stand out from the usual picture, one of them being the group find of silver coins discovered in grave 241 . The grave was excavated during the campaign of 2014 in the north-eastern part of the trench. It was superimposed over earlier graves $\mathrm{G} 240$ and $\mathrm{G} 243$. The ${ }^{14} \mathrm{C}$ method dated the deceased individual from grave 240 to the second half of the $12^{\text {th }}$ century or the first half of the $13^{\text {th }} .{ }^{6}$ During the excavation, it was discovered that part of grave 241 crosses over the edge of the trench, and therefore the skull and the left portion of the torso of the individual were not excavated (Fig. 2)

A man aged between 30 and 35 at the time of death was buried in the grave. Between his legs, level with his pelvic bones, a group find of silver coins, probably originally placed in a bag made of organic material, was discovered (Figs 3, 4). Twentyone pieces of silver coin were discovered (Fig. 5). Most of them can be identified as denarii banales (15 pieces), minted during the reigns of kings Béla IV, Stephen V and Ladislaus IV. It is the largest quantity of denarii banales discovered in a single grave in Croatian territory. Six denars minted during the reign of King Stephen $\mathrm{V}$ were discovered alongside them. This find enables us 
(Schmorlovi defekti) pronađeni su na 9., 10., 11. i 12. prsnom te 1. slabinskom kralješku. Ova je osoba također za života preboljela određene upalne procese koji su ostavili trag na kostima u vidu blagoga zaraslog periostitisa na goljeničnim i lisnim kostima. $U$ trenutku smrti pokojnik je bolovao od infekcije koja je prouzročila aktivan periostitis na 5 . slabinskom kralješku i križnoj kosti te vjerojatno i makroporozitet na lijevoj zdjeličnoj kosti. Vjerojatno se radi o brucelozi. Na periode fiziološkog stresa u djetinjstvu upućuju zubima prisutni hipoplastični defekti.? Kao što vidimo, radi se o osobi koja svoj socijalni položaj nije dobila rođenjem, nego ga je zaslužila tijekom života.

\section{Novac kao prilog u grobu}

Arheološka istraživanja i povijesni izvori sugeriraju nam da običaj polaganja kovanica u grobove pokojnika ima veoma dugu tradiciju. Tijekom antike takva praksa povezuje se s mitom o Haronu, lađaru koji je duše umrlih prevozio preko rijeke Aheront u Had. No za svoj posao morao je biti plaćen pa se $\mathrm{s}$ preminulima u grob stavljala kovanica koja je trebala poslužiti u tu svrhu. lako nešto rjeđe, praksa prilaganja kovanice u grob nastavila se i tijekom srednjeg i novog vijeka. U grobovima tog perioda kovanice se nalaze na različitim položajima oko pokojnika. Prisutne su unutar i oko usta, oko očiju, zatim pored glave ili ramena, kukova, ispod glave, na prsima, na pojasu, u rukama, ušivene u odjeću i kao ukras na odjeći ili dio nakita. ${ }^{8}$ Novac se povremeno nalazi i u zapuni grobova, ali u tom slučaju ne možemo sa sigurnošću tvrditi da pripada ukopanom pokojniku i da u grob nije dospio slučajno. Razloge prilaganja kovanica u grobove tijekom srednjeg i novog vijeka ne možemo tražiti u antičkim mitovima i svaki je nalaz potrebno individualno promatrati. Najjednostavnije je protumačiti nalaze probušenog novca koji je služio kao privjesak ili bio prišiven na odjeću. Njegova je uloga bila estetska, odnosno služio je kao dio osobnog nakita i nije imao simboličnu ulogu. ${ }^{9}$ Prilog jedne ili dvije kovanice na ili ispod tijela pokojnika sigurno je bio dio pogrebnog rituala $i$ imao je neku simboličnu ulogu. Novac je najvjerojatnije imao funkciju obola, ${ }^{10}$ apotropejskog sredstva ili je, budući da pripada kršćanskim vladarima, trebao potvrditi kršćansku prirodu pogrebnog obreda, kako to smatra C. V. Lorenzo. ${ }^{11}$ Brojne razloge priloga novca u grob donosi nam i etnološka literatura. Tako B. Đaković objedinjuje te razloge u tri glavne grupe. U prvoj su grupi razlozi koji podrazumijevaju da se pokojnik neko vrijeme to classify the deceased man, in whose grave it was discovered, in the higher social stratum of the Torčec community. However, the anthropological analysis of the skeleton does not confirm that conclusion. Traces of hard manual labour (Schmorl's nodes) were discovered on the $9^{\text {th }}, 10^{\text {th }}, 11^{\text {th }}$ and $12^{\text {th }}$ thoracic vertebrae and the $1^{\text {st }}$ lumbar vertebra. This person also recovered from in flammations that left traces on his bones in the form of healed mild periostitis on his tibiae and fibulae. At the time of death, the deceased individual had an infection that resulted in the active stage of periostitis on his $5^{\text {th }}$ lumbar vertebra and sacrum, and probably macroporosity of his left pelvic bone. Possibly, this was caused by brucellosis. Enamel hypoplasia present on his teeth also points to periods of physiological stress in his childhood.? As we can see, this individual did not gain his social position by birth, but earned it during his lifetime.

\section{Coins as grave goods}

Archaeological excavations and historical sources suggest that there is a long tradition of adding coins to graves. In antiquity, this practice was linked to a bribe given to Charon, the ferryman transporting the souls of the deceased over the Acheron to Hades. But he had to be paid for his work, and therefore a coin serving that purpose was placed in the grave with the deceased. Although not as common, the practice of laying coins in graves continued during the Middle Ages and the early modern period. In graves from those periods, coins can be found in various positions around the deceased individuals. They were situated within and around the mouth or the eyes, next to the head or shoulders, by the hips, beneath the head, on the chest, on the waist, in the hands, sewn into the clothes, and as decorations on the clothes or as part of the jewellery. ${ }^{8}$ Coins can periodically be found in the fill of the graves; but, in that case, we cannot be certain they belonged to the buried individual as opposed to having got into the grave by chance. The reasons behind placing coins in graves during the Middle Ages and the modern period should not be searched for in ancient myths; rather, every find needs to be studied individually. The finds of pierced coins that served as pendants or were sewn onto the clothes are the easiest to interpret. Their role was aesthetic, i.e. they served as personal jewellery items and had no symbolic function. ${ }^{9}$ One or two coins on or below the body of the deceased individual were certainly a part of the funerary rite and had some symbolic function. The coins probably had the function of an obolus, ${ }^{10}$ an apotropaic function, or - according to C.V. Lorenzo - since they belonged to Christian rulers, they were supposed to confirm the Christian nature of the funerary rite. ${ }^{11}$ Numerous reasons

\footnotetext{
Šlaus et al. 2015, 121.

Ruttkay 1989, 356; Demo 2007, 92; Králíková 2007, 136-138; Gilchrist 2008, 133-135; Mašić, Pantlik 2008, 336; Tkalčec 2011, 38.

Mirnik 2004, 213; Filipec 2012, 151-153; Krznar 2014, 228; Tomičić 2019, 192-193

10 Demo 2013, 119.

11 Lorenzo 2008, 422
}

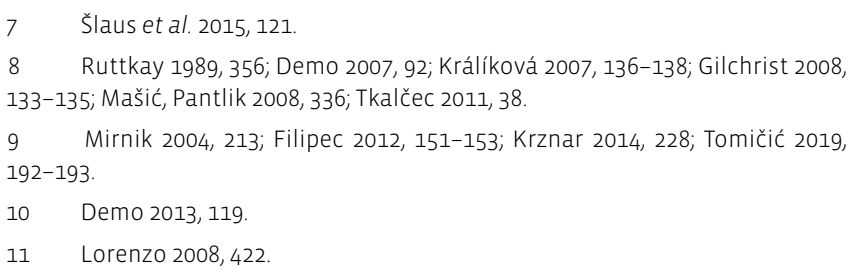


zadržava u blizini, u zagrobnom životu, kao primjerice, da plati kuću, da plati mir na zemlji ili da plati mjesto. U drugoj su grupi razlozi koji se dovode u vezu sa strahom od pokojnika: da se ne povampiri, da se ne vraća, da ne ide praznih ruku, da ne nosi sreću iz kuće, da ga se isplati, da se otkupi ostavljena imovina ili stoka tako da je pokojnik ne bi povlačio za sobom. U treću grupu razloga pripadaju oni prema kojima je novac služilo kao nagrada za plaćanje puta, prijelaza preko rijeke, prijevoza na otok blaženih, da pokojnik kupi kuću na onome svijetu ili da pokojnik otplati dugove i plati grijehe..$^{12}$

Osim u funkciji nakita ili obola, novac se u grobovima pojavljuje u još jednoj formi. Radi se o nalazima većeg broja kovanica u grobu koji se ne mogu objasniti s prethodno navedenim funkcijama. Ovakvi nalazi su znatno rjeđi od ostalih. Osim nalaza iz Torčeca, koji se ovdje obrađuje, možemo još spomenuti nalaze s lokaliteta Sv. Emerik ispod Kamengrada (G 77 - 10 kovanica), ${ }^{13}$ Novi sokak u Vukovaru (oko 1000 kovanica), ${ }^{14}$ Sv. Franjo na Opatovini (G 166 - 6 kovanica) ${ }^{15}$ i park Grič (G $74-14$ kovanica $)^{16} \mathrm{u}$ Zagrebu, Sv. Martin kod Sukošana (G1 - 130 kovanica, G2 - 30 kovanica $)^{17}$ te trg Pul Vele crikve u Rijeci (G 40 - 70 kovanica). ${ }^{18}$ Novac je na ovim lokalitetima uglavnom pronađen u vrećicama od organskog materijala ili ušiven u odjeću pokojnika. Za novac ušiven u odjeću autori nisu sigurni radi li se o namjernom prilogu ili je novac ukopan slučajno, kao što to smatraju Mašić i Pantlik za nalaz iz Parka Grič. ${ }^{19}$ U Rijeci i grobu 2 iz Sukošana novac je pronađen uz glavu pokojnika i sasvim je sigurno da je namjerno priložen uz grob, ali autori, nažalost, ne donose moguće razloge tog postupka.

\section{Analiza denara iz groba 241}

Među pronađenim kovanicama većinu čine slavonski banski denari (denarii banales), koji se često u literaturi pogrešno nazivaju „banovci“, a koji se prvi put počinju kovati u vrijeme vladavine kralja Bele IV. (1235. - 1270.). U najranijoj fazi distribucije, zbog svojih iznimnih stilskih karakteristika i izrade od srebra s malim postotkom primjese zlata i bakra, ovaj je novac iznimno popularan na prostoru današnje Hrvatske, ali i izvan njenih gra- for adding coins to graves can also be found in ethnological literature. For instance, B. Đaković classifies the reasons into three main groups. The first one includes reasons that imply that the deceased individual stays nearby for some time, in the afterlife. For instance, to pay for the house, peace on Earth, or the plot. The second group includes reasons linked to a fear of the deceased individual. For instance, so they would not turn into a vampire, so they would not return, so they would not go empty-handed, so they would not take the luck out of the house with them, to pay them off, to pay for the property or livestock left behind so that the deceased individual would not take it with them. The third group of reasons includes those according to which the coins served as reward used for paying for the journey, crossing the river, for paying for transport to the Island of the Blessed, for the deceased individual to buy a house on the other side, or to pay off a debt or pay for his sins. ${ }^{12}$

Aside from the function of jewellery or obolus, coins found in graves come in one more form. Those are finds of a larger amount of coins in the grave, which cannot be explained by the aforementioned functions. These finds are much rarer than the others. Aside from the Torčec find analysed in this paper, we can also mention finds from the site of St Emeric, beneath Kamengrad (G 77: 10 coins), ${ }^{13}$ the site of Novi sokak in Vukovar (around 1000 coins), ${ }^{14}$ the sites of St Francis, at Opatovina (G 166: 6 coins), ${ }^{15}$ and Grič Park (G 74: 14 coins) ${ }^{16}$ in Zagreb, the site of St Martin near Sukošan (G 1: 130 coins, G 2: 30 coins), ${ }^{17}$ and the Square of Pul Vele crikve in Rijeka (G 40: 70 coins). ${ }^{18}$ At these sites, money was discovered mostly in bags made of organic material or sewn into the clothes of the deceased individual. The authors are not certain whether the sewn-in money was intentionally added to the grave or was buried by chance, as Mašić and Pantlik believe for the Grič Park find. ${ }^{19}$ In Rijeka and grave 2 at Sukošan, the money was discovered next to the heads of the deceased and was absolutely certainly added to the graves on purpose, but unfortunately the authors do not provide possible reasons for that.

\section{Analysis of coins from grave 241}

Most of the coins discovered are Slavonian denarii banales, of ten erroneously called 'banovci' in the literature, which were minted for the first time during the reign of King Béla IV (12351270). Their exceptional stylistic characteristics and the fact that they were made of silver with a small percentage of gold and copper made these coins, in the earliest phase of their distribution, extremely popular not only in the territory of today's

$\begin{array}{ll}12 & \text { Đaković 1987, 55-57. } \\ 13 & \text { Demo 1984, 344-350. } \\ 14 & \text { Mirnik 1984; 1994. } \\ 15 & \text { Demo 2007, 43, 91-92. } \\ 16 & \text { Mašić, Pantlik 2008. } \\ 17 & \text { Vučić 2006, 217. } \\ 18 & \text { Bekić 2010. } \\ 19 & \text { Mašić, Pantlik 2008, 336. }\end{array}$

12 Đaković 1987, 55-57.

13 Demo 1984, 344-350.

14 Mirnik 1984; 1994.

15 Demo 2007, 43, 91-92.

16 Mašić, Pantlik 2008.

17 Vučić 2006, 217.

18 Bekić 2010

19 Mašić, Pantlik 2008, 336 
nica. ${ }^{20}$ Denar se još dijelio u manje jedinice, poput obola koji su iznosili polovicu denara i kovali se od jednake smjese kao i veća jedinica. ${ }^{21}$

Glavnu ulogu u njihovu kovanju imali su hercezi i banovi²2 pa ovaj novac ujedno može poslužiti i kao dokaz svojevrsne autonomnosti slavonskog društva tijekom 13. i 14. stoljeća. Stoga, ne čudi podatak da zbog njihove iznimne vrijednosti, banske denare pronalazimo unutar ostava s novcem ili, u ovom slučaju, uz pokojnika, vjerojatno kao popudbinu za zagrobni život. ${ }^{23}$ Također, tijekom ovog perioda aktualna je i učestala zamjena starog novca za novi, i to ne samo na Hrvatskom, već na prostoru čitave Ugarske, čemu je prethodila Belina ekstenzivna monetarna reforma. ${ }^{24}$ To je bilo uobičajeno u periodu kada je kovnica izrađivala, odnosno od Martinja do kraja godine. ${ }^{25}$ Upravo zbog konstantne zamjene novca, s vremenom postaje sve lošiji. Same kalupe za kovanje najčešće su izrađivali priučeni graveri pa je izgled kovanice u velikoj mjeri ovisio o njihovoj spretnosti, ali i brzini njegova trošenja. ${ }^{26}$ Učestala promjena kalupa tako uvjetuje različitim varijantama prikaza i natpisa na novcu, što je vidljivo i na ovdje obrađenim primjercima.

Banski denari analizirani u nastavku kovani su za vrijeme arpadskih kraljeva Bele IV. (1235. - 1270.), Stjepana V. (1270. - 1272.) i Ladislava IV. (1272. - 1290) i pod namjesništvima raznih banova. ${ }^{27}$ Sve ih karakteriziraju gotovo jednaki prikazi na aversu i reversu. Na licu denara nalazi se natpis Moneta regis p(ro) Sclavonia, smješten unutar dvije biserne kružnice s križem koji označava početak i kraj teksta. U središnjem polju kovanice nalazi se kuna u trku, okrenuta na lijevo sa šesterokrakom zvijezdom iznad i ispod, koja, prema Wyroubalu, predstavlja dvije rijeke koje omeđuju Slavoniju: Savu i Dravu. ${ }^{28}$

Revers je kovanice nešto kompleksniji i na njemu se pojavljuje nekoliko motiva. Unutar biserne kružnice dominira patrijarhalni križ na dvije stepenice, sastavljen od patibuluma i dvije (jedne veće i jedne manje) poprečne grede ili antene. Pored gornjeg dijela križa, na lijevoj strani, nalazi se šesterokraka zvijezda, dok je na desno, ukoso, položen polumjesec između čija dva kraka se nalazi kružić s točkom ili ljiljan. Moguće su i varijacije u prikazima, u kojima dolazi do zamjene u poziciji prethodno navedenih elemenata, što je zastupljeno i na ovdje obrađenim primjercima. Iz središta križa niču dva Ijiljana ili pupoljka. Ispod
Croatia, but also outside its borders. ${ }^{20}$ The denarius banalis was divided into smaller units, such as oboli, worth half a denarius banalis and minted from the same alloy as the larger unit. ${ }^{21}$

Bans $^{22}$ and dukes ${ }^{23}$ played the main role in minting them, so this money can also serve as proof of a certain autonomy of the society of Slavonia during the $13^{\text {th }}$ and $14^{\text {th }}$ centuries. Therefore, it is no surprise that, due to their high value, we find denarii banales in money hoards or, in this case, next to a deceased individual, possibly as travelling provisions for the afterlife. ${ }^{24}$ Likewise, during this period, a substitution of old currency for new was common, in the territory not only of Croatia but also of Hungary, after Béla's extensive monetary reform. ${ }^{25}$ That was common in the period when the mint operated, i.e. from St Martin's Day to the end of the year. ${ }^{26}$ It was precisely the constant substitution of currency that caused its quality to decrease over time. The coin dies for minting were usually produced by non-professional engravers, and the appearance of the coin depended mostly on their skills, and also how fast they wore out. ${ }^{27}$ Frequent replacing of the dies resulted in different variants of the images and inscriptions on the coins, visible on the examples analysed here, as well.

The denarii banales analysed below were minted during the reigns of kings of the Árpád dynasty - Béla IV (1235-1270), Stephen V (1270-1272) and Ladislaus IV (1272-1290) - and under various bans. ${ }^{28}$ They are all characterized by almost the same images on obverse and reverse. The coins' fronts contain the inscription Moneta regis $p(r o)$ Sclavonia placed within two pearl circles with a cross marking the beginning and the end of the text. The centre of the coins contains a running marten facing left with one six-pointed star above it and one below, which, according to Wyroubal, represent the two rivers that bound Slavonia: the Sava and Drava. ${ }^{29}$

The reverse of the coin is somewhat more complex and contains several motifs. A patriarchal cross on two steps made of patibulum and two transverse beams or antennae (one larger and one smaller) dominates within the pearl circle. Next to the top part of the cross, on the left, there is a six-pointed star, while on the right there is a tilted crescent moon, and between its arms a circle enclosing a dot or lily. The positions of the images can vary, so the aforementioned elements can be transposed, as

\footnotetext{
21 Truhelka 1897, 38

22 Prema Truhelki, nejasno je jesu li banovi pravo kovanja novca (Ius cudendae monetae) sami prisvojili ili im je dodijeljeno od strane vladara (Truhelka 1897, 4.)

23 Székely 1980, 102-104

24 Gyöngyössy, Winter 2007, 19-20

25 Truhelka 1897, 11; Križan 2010, 9

26 Dobrinić 1993, 53

27 lako su ovaj tip novca kovali i hercezi, za primjerke obrađene u nastavku ovog rada možemo reći da su isključivo rađeni pod banskim namjesništvom. Tomu u prilog ide činjenica da hercezi na kovanicu stavljaju natpis MO-
} NETA DVCIS P SCLAVONIA

28

Wyroubal 1981, 8

\footnotetext{
20 Székely 1980, 102-104; Štefan 2019, 179

21 Truhelka 1897, 38

22 Translator's note: 'Ban' is a title given to the legal representative of the king in medieval Croatia, Slavonia and Bosnia.

According to Truhelka, it is unclear whether bans claimed the right to mint currency (Ius cudendae monetae) themselves or if it was granted to them by the ruler (Truhelka 1897, 4)

24 Székely 1980, 102-104.

25 Gyöngyössy, Winter 2007, 19-20.

26 Truhelka 1897, 11; Križan 2010, 9.

27 Dobrinić 1993, 53

28 Although this type of coin was minted under dukes as well, we can say that the coins analysed below had been minted exclusively under the authority of a ban. The fact that dukes mark the coin with MONETA DVCIS P SCLAVONIA supports this thesis
}

29

Wyroubal 1981, 8 


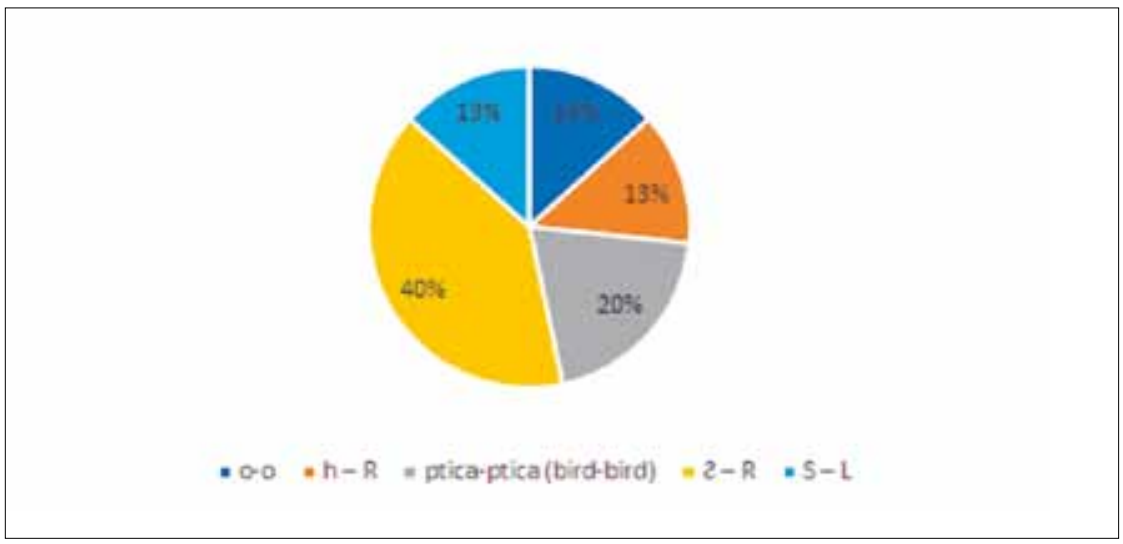

SLIKA 6. Omjer banskih denara prema siglama (izradio L. Štefan).

FIGURE 6. Ratios of denarii banales by siglum (made by L. Štefan).

veće poprečne grede nalaze se dvije okrunjene glave, okrenute jedna prema drugoj, koje predstavljaju kralja i kraljicu. ${ }^{29} \mathrm{Uz}$ istu se nalazi i sigla koja označava pod čijom je vladavinom ili namjesništvom nastala kovanica.

Od pronađenih denara, dva (kat. br. 1 i 2) nose oznaku o-o te su bili kovani pod hercegom i banom Dionizijem između 1242. i 1245. godine ( $14 \%$, sl. 6). Isto toliko je i primjeraka kovanih pod banovima Rolandom (1261. - 1267.) i Henrikom II. Gisingovcem (1267. - 1269.), koji su na kovanice stavljali jednake sigle, h-R, što čini ukupno 13 \% slavonskih banskih denara unutar ovog skupnog nalaza (kat. br. 3 i 4). Kasnije, između 1267. i 1269. godine, potonji ban odlučuje proizvoditi kovanice s gotovo jedinstvenom siglom - čime izlazi iz okvira standardnog označavanja novca slovima ili kružićima (kat. br. 5-7). Ovaj tip kovanice čini ukupno 20 \% slavonskih banskih denara, dok novac kovan za vrijeme bana Joakima Pektara (1270. - 1272., sigla S - R) dominira i sa šest primjeraka čini 40\% nalaza (kat. br. 8-13). Preostala dva primjerka s oznakom S - L najmlađa su među slavonskim banskim denarima i kovani su pod namjesništvom različitih banova i podbanova (kat. br. 14 i 15).

Banski su denari kovani u dvije kovnice. Za dva pronađena primjerka možemo ustvrditi da su kovani u kovnici u Pakracu (camera de Puchruch), gdje vjerojatno i nastaju najljepši primjerci ovog novca (kat. br. 1-2). Ostatak primjeraka, gledajući njihove stilske karakteristike i oznake, kovano je u Zagrebu, gdje je kovnica preseljena zbog ekonomskog prosperiteta grada, time formirajući novu monetarnu provinciju na prostoru Ugarske. ${ }^{30}$ $\mathrm{Na}$ taj način Slavonska kovnica postaje kraljevska komora, gdje ban koristi pravo kovanja novca kao kraljev zastupnik. ${ }^{31} \mathrm{Uz}$ to, seen in the examples analysed in this paper, as well. Two lilies or buds come out of the centre of the cross. Below the larger transverse beam, two crowned heads face each other, representing the king and queen. ${ }^{30} \mathrm{Next}$ to it there is a siglum, marking under whose reign or governance the coin was minted.

Of the coins discovered, two (cat. nos 1 and 2) bear the mark 0-0 and were minted under Duke and Ban Dionysius, between 1242 and 1245 ( $14 \%$, Fig. 6). The same number of the coins discovered were minted under bans Roland (1261-1267) and Henry I Kőszegi (1267-1269), who put the same siglum on their coins ( $h-R$, ) mak ing up $13 \%$ of Slavonian denarii banales within this group find (cat. nos 3 and 4). Later on, between 1267 and 1269, the latter ban decided to produce coins with an almost unique siglum ( - breaking the settled rules of marking coins with let ters and circles (cat. nos 5-7). This type of coins makes up $20 \%$ of the Slavonian denarii banales, while the money minted under Ban Joachim Gutkeled (1270-1272, siglum S - R) dominates with six coins and makes up $40 \%$ of the find (cat. nos $8-13$ ). The two remaining coins, with the mark $S-L$, are the latest Slavonian denarii banales and were minted under various bans and vicebans (cat. nos 14 and 15).

Denarii banales were minted in two mints. We can ascertain that two of the coins discovered were minted in the mint at Pakrac (camera de Puchruch), from where the nicest examples of this money probably originated (cat. nos 1-2). The rest of the coins, according to their stylistic characteristics and marks, were probably minted in Zagreb, where the mint was transferred as a result of the town's economic prosperity. This introduced a new monetary province to the territory of Hungary. ${ }^{31}$ In that way, the Slavonian mint became the Royal Chamber, in
29 Pretpostavka da se radi o kralju i kraljici polazi iz činjenice da oboje imaju pravo na nošenje krune, dok nedostatak svetokruga oko glava isključu je mogućnost da se radi o svetim vladarima Stjepanu I. i Ladislavu I. (Truhelka 1897, 52; Mirnik 2008, 129.). Isto je smatrao i Pavao Ritter Vitezović, napisavši u svom dijelu Banologija da se često ipak kod starih spisateljah spominju, a i danas gdiekad nalaze banski denari, imena Slavonskog novca, kao i isti banski sreberni novac, sa gerbom (stemate) kraljevstva Slavonskog, dvostrukim kerstom na podnožju između kralja i kraljice, kunom izmedju dvijuh zviezdah (HAZU Archive: P. Ritter Vitezović, Banologija seu de banatu Chroatiae; Korčmaroš 1998, 90)

30 Metcalf 1965, 165; Kampuš 1981, 10; Štefan 2019, 179-180.

31 Székely 1980, 80-84.
30 Presumably, these are a king and a queen, since they both have the right to bear a crown, while the possibility that they are the holy rulers Ste phen I and Ladislaus I is ruled out by the lack of aureoles around their heads (Truhelka 1897, 52; Mirnik 2008, 129). Pavao Ritter Vitezović believed the same when, in his paper Banologija, he wrote that often "still, old writers mention denarii banales, which can sometimes be discovered today as well, a Slavo nian currency, as well as the same silver currency of bans, with the coat of arms of the Kingdom of Slavonia, double cross below, in the area between the king and the queen, a marten between two stars" (HAZU Archive: P. Ritter Vitezović, Banologija seu de banatu Chroatiae; Korčmaroš 1998, 90).

31 Metcalf 1965, 165; Kampuš 1981, 10; Štefan 2019, 179-180. 
SLIKA 7. Omjer denara prema tipu (izradio L. Štefan). FIGURE 7. Ratio of denar coin types (made by L. Štefan).

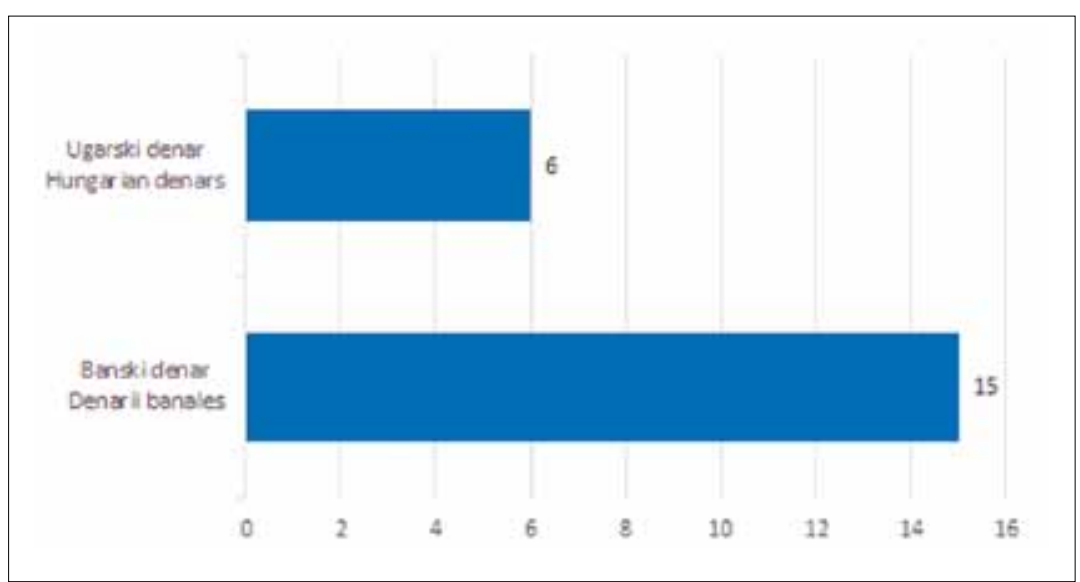

premještanju su vjerojatno pridonijeli i sukobi ostrogonskog nadbiskupa i zagrebačkog biskupa, s obzirom na to da se Pakrac nalazio na rubnom i spornom području bez utvrđenih granica. ${ }^{32}$

Sve promjene i varijacije u nastanku kovanica bit će naznačene u popratnom katalogu.

Uz banske denare na prostoru hrvatske kolali su i drugi novci, poput ugarskih denara Stjepana V., koji se pojavljuju kao dio ovog značajnog nalaza i čine $29 \%$ od ukupnog broja kovanica (sl. 7, kat. br. 16-21). Možemo pretpostaviti da ljudi tijekom spomenutog perioda u posjed ovog novca dolaze zahvaljujući trgovini i povoljnim državno-pravnim odnosima s Ugarskom. Na aversu kovanice nalazi se jednostavan natpis u više redova *S*/TEPh/ ANRE $/{ }^{*} *{ }^{* 33}$ Revers pak krasi prikaz okrunjenoga kralja na tronu, koji drži kraljevsku jabuku (lat. Globus Cruciger) u desnoj i žezlo (lat. sceptar) u lijevoj ruci. S lijeve i desne strane glave nalazi se po jedna šesterokraka zvijezda. Uz vladara nalazi se zasad još uvijek nedeterminirana sigla $M-*$, no moguće je da se radi o oznaci lokalnoga komornog grofa Mihaela iz Ostrogona. ${ }^{34}$

\section{Zaključak}

Na primjeru ovog ukopa, možemo postaviti pitanje je li pokojnik pripadao višem društvenom staležu s obzirom na količinu srebrnog novca koju je imao kod sebe, a koja nije sadržavala ni jedan obol? Odgovor na ovo pitanje je kompleksan. Zanimljivo je da je pokojnik ukopan s iznosom, kojim je mogao platiti porez (tzv. collecta septem denariorum), koji je tada iznosio 7 denara za kućanstvo, ${ }^{35}$ a vjerojatno si je još mogao priuštiti i jednu do dvije kuneće kože, za koju znamo da je u prvoj polovici 14. stoljeća vrijedila 17 denara, ${ }^{36}$ dok je vjerojatno još za vrijeme vla- which the ban used the right to mint currency as the representative of the king. ${ }^{32}$ Likewise, conflicts between the Archbishop of Esztergom and the Bishop of Zagreb probably contributed to the transfer as well, given that Pakrac was situated in a peripheral and contested area outside established orders. ${ }^{33}$

All changes and variations in the production of the coins will be noted in the accompanying catalogue.

Alongside denarii banales, other currencies were also used in the territory of Croatia, such as King Stephen V's Hungarian denars, which appear as part of this significant find and make up $29 \%$ of the total number of coins (Fig. 7, cat. nos 16-21). We can assume that people acquired this currency in this period owing to trade and favourable inter-state and legal relations with Hungary. The coins' obverses contain a simple inscription on several lines, *S*/TEPh/ANRE/* $X *{ }^{* 34}$ The reverse is decorated with an image of a crowned king on a throne holding an imperial orb (Lat. Globus Cruciger) in his right hand and a sceptre (Lat. sceptar) in his left. There is one six-pointed star on the right side of the head, and one on the left. Alongside the ruler, there is a so-far undetermined siglum, $M-*$, but it is possible that it was a mark of a local chamber count Michael of Esztergom. ${ }^{35}$

\section{Conclusion}

On the basis of this burial, we can pose the question of whether the deceased individual belonged to a higher social stratum, given the number of silver coins he was buried with, and that they did not include a single obolus. The answer to this question is complex. Interestingly, the deceased individual was buried with an amount which could serve for paying taxes (the so-called collecta septem denariorum), which amounted to 7 denarii banales for a household, ${ }^{36}$ and he could probably also afford one or two marten pelts, which we know cost 17 dena- 
davine Stjepana V. bila jeftinija. ${ }^{37}$ Često je iznos poreza ovisio i o veličini imanja pa je tako za jednu kuriju iznosio 300 denara, a za njenu polovinu $150 .{ }^{38}$ Također, sama činjenica da se uz banske denare nalazi i ugarski novac ide u prilog ideji o imućnijem članu zajednice pa čak i osobi koja se bavila nekim oblikom trgovine izvan granica Slavonije, vjerojatno na prekodravskom prostoru. Uzmemo li u obzir dokaze teškoga fizičkog rada na kostima muškarca, zaključak koji se nameće je da se radi o srednjovjekovnom poljoprivredniku, vjerojatno stočaru ako je dijagnoza zaraze brucelozom ispravna. No, uza sve dokaze koji idu u prilog tome da se radi o bolje stojećem pojedincu i da su kovanice pronađene uz tijelo muškarca njegova osobna imovina, to je teško dokazati. Ako je tako, o razlozima zbog kojih su se njegovi bližnji i njegova zajednica odlučili pokopati toliku količinu kovanica, možemo samo spekulirati. lako manje vjerojatno, ne može se sa 100-postotnom sigurnošću isključiti ni mogućnost da je novac u grob stavljen isključivo kao prilog i da nije izravno pripadao pokojniku.

\section{SLAVONSKI BANSKI DENARI}

\section{Kralj Bela IV. (1235. - 1270.)}

Herceg i ban Dionizije (1242. - 1245.)

Kovnica: Pakrac

+MONETAREGISPSCLAONIA

\section{Bilješka:}

Av.: Slova N i E u abrevijaciji.

Rv.: Iz središta križa sa svake strane izlazi stilizirani pupoljak. Točka na vrhu patibuluma.

\section{PN 159_3}

Sigla: 0 - 0

Materijal: srebro; Orijentacija: 12; Mjere: 17 mm; Težina: 0.95 g.

2. PN 159_4

Vidljiv dvostruki udarac na kovanici.

Sigla: 0 - o

Materijal: srebro; Orijentacija: 2; Mjere: 17 mm; Težina: $1.02 \mathrm{~g}$

Bibliografija: Rengjeo 1959, kat. br. 69; Dolenec 1993, kat. br. 26 var.; Gyöngyössy, Winter 2007, kat. br. 1709, 1710.

Ban Roland (1261. - 1267.); Ban Henrik II. Gisingovac (1267. - 1269.)

36 Benažić 2001, 75.

37 Uzrok varijaciji u cijeni je pad vrijednosti i kvalitete, prije svega banskog denara, za vrijeme Andrije trećeg, što se nastavlja dolaskom Anžuvinaca na vlast (Štefan 2019, 180.), s čime raste i porez, koji u 14. stoljeću iznosi 21 denar.

38 Kampuš 1982, 11 rii banales ${ }^{37}$ each in the first half of the $14^{\text {th }}$ century, while they were probably still cheaper during the reign of King Stephen $\mathrm{V}^{38}$ The amount of tax to be paid often depended on the size of the estate; it was 300 denarii banales for a whole manor-house estate and 150 denarii banales for half of one. ${ }^{39}$ Likewise, the mere fact that Hungarian currency was discovered alongside denarii banales supports the idea that this was a more well-off member of the community, or even a person practising some type of trade outside Slavonian borders, perhaps in the area across the River Drava. Considering the traces of hard labour on this man's bones, we conclude that he was a medieval farmer, probably a herdsman, if the brucellosis diagnosis is correct. But, despite all the evidence pointing to this being a well-off individual and the coins discovered alongside his body being his personal property, that is difficult to prove. If that is so, we can only speculate on the reasons why his kin and community decided to bury such a large quantity of coins. Although it is less likely, we cannot completely disregard the possibility that the money was put in the grave only as a grave good, and that it did not belong directly to the deceased individual.

\section{SLAVONIAN DENARII BANALES}

\author{
King Béla IV (1235 - 1270) \\ Duke and Ban Dionysius (1242 - 1245) \\ Mint: Pakrac \\ +MONETAREGISPSCLAONIA
}

Note:

OBV: Letters $\mathrm{N}$ and $\mathrm{E}$ in abbreviation.

REV: Stylized bud comes out of the centre of the cross on each side. Dot on the top of the patibulum.

\section{1. SF 159_3}

Siglum: 0 - 0

Material: silver; Axial orientation: 12; Dimensions: $17 \mathrm{~mm}$; Weight: $0.95 \mathrm{~g}$.

\section{SF 159_4}

Double strike visible on the coin.

Siglum: 0 - o

Material: silver; Axial orientation: 2; Dimensions: $17 \mathrm{~mm}$ Weight: $1.02 \mathrm{~g}$.

Bibliography: Rengjeo 1959, cat. no. 69; Dolenec 1993, cat. no. 26 var.; Gyöngyössy, Winter 2007, cat. nos 1709, 1710.

Ban Roland (1261 - 1267); Ban Henry I Kőszegi (1267 - 1269)

\footnotetext{
37 Benažić 2001, 75

38 The reason for this variation in cost is the fall in value and quality, es pecially of denarii banales, during the reign of King Andrew III, which continued when the House of Anjou came to power (Štefan 2019, 180), causing the growth in taxes, amounting to 21 denarii banales in the $14^{\text {th }}$ century.

39 Kampuš 1982, 11
} 


\section{Kovnica: Zagreb}

+MOnETA $\because$ REGISPSCLA $\because$ OnIA

Bilješka:

Av.: Tri sitne točkice između slova A i R. Jasno vidljiv prikaz ljiljana između abrevijacije $\mathrm{A}$ i slova $0 .{ }^{39}$

Rv.: Iz središta križa sa svake strane izlazi Ijiljan. Vrh patibuluma spojen s bisernom kružnicom. Unutar zvijezde na lijevo nedostaje točka. Iznad sigla cirkumfleks.

\section{PN 159_5}

Sigla: $\mathrm{h}-\mathrm{R}$

Materijal: srebro; Orijentacija: 6; Mjere: 16 mm; Težina: $1.01 \mathrm{~g}$.

\section{PN 159_14}

Sigla: h-R

Materijal: srebro; Orijentacija: 6; Mjere: 16 mm; Težina: $1.00 \mathrm{~g}$.

Bibliografija: Rengjeo 1959, kat. br. 97 - 100 var.; Dolenec 1993., kat. br. 30; Gyöngyössy, Winter 2007, kat. br. 1721, 1722.

Ban Henrik II. Gisingovac (1269. - 1270.)

Kovnica: Zagreb

+MOnETA $\because$ REGIS $:$ PSCLAOnI $\because A \%$

Bilješka:

Av.: Tri sitne točkice ili stilizirana ljiljana između pojedinih slova.

Rv.: Iz središta križa sa svake strane izlazi ljiljan. Vrh patibuluma spojen s bisernom kružnicom. Unutar zvijezde na lijevo nedostaje točka.

\section{PN 159_6}

Sigla:

Materijal: srebro; Orijentacija: 11; Mjere: 16 mm; Težina: $1.02 \mathrm{~g}$.

\section{PN 159_9}

Sigla:

Materijal: srebro; Orijentacija: 11; Mjere: 15 mm; Težina: $0.87 \mathrm{~g}$.

7. PN 159_15

\section{Mint: Zagreb}

+MOnETA $\because$ REGISPSCLA $\because$ OnIA

Note:

OBV: Three small dots between the letters A and R. Clearly visible image of lilies between abbreviation $\mathrm{A}$ and letter $0.4^{40}$

REV: Lily comes out of the centre of the cross on each side. Top of patibulum is linked by a pearl circle. Dot missing within the star on the left. Circumflex above the siglum.

3. SF 159_5

Siglum: $h-R$

Material: silver; Axial orientation: 6; Dimensions: 16 mm; Weight: $1.01 \mathrm{~g}$.

\section{SF 159_14 \\ Siglum: h - R}

Material: silver; Axial orientation: 6; Dimensions: $16 \mathrm{~mm}$; Weight: $1.00 \mathrm{~g}$.

Bibliography: Rengjeo 1959, cat. nos 97-100 var.; Dolenec 1993, cat. no. 30; Gyöngyössy, Winter 2007, cat. nos 1721, 1722.

Ban Henry I Köszegi (1269 - 1270)

Mint: Zagreb

+MOnETA $\because$ REGIS $:$ PSCLAOnI $\because A:$

Note:

OBV: Three small dots or stylized lilies between certain letters.

REV: Lily comes out of the centre of the cross on each side. Top of patibulum is linked with a pearl circle. Dot missing within the star on the left.

5. SF 159_6

Siglum:

Material: silver; Axial orientation: 11; Dimensions: $16 \mathrm{~mm}$; Weight: $1.02 \mathrm{~g}$.

6. SF 159_9

Siglum:

Material: silver; Axial orientation: 11; Dimensions: $15 \mathrm{~mm}$; Weight: $0.87 \mathrm{~g}$.

7. SF 159_15
39 Smajlagić smatra da se pojava tri točkice među slovima može interpretirati kao Sv. Trojstvo (Smajlagić 2013, 38-43), no moguće je da se radi o stiliziranom prikazu ljiljana kakav se pojavljuje između spomenutih slova na ovim primjercima.
40 Smajlagić believes that the appearance of three dots between the let ters can be interpreted as the Holy Trinity (Smajlagić 2013, 38-43), but it is possible that these are stylized images of lilies that can be found between the aforementioned letters on these coins. 
Zbog nezgrapne izrade i značajnim promjenama u izvedbi, osobito na reversu, moguće je da se radi ili o promjeni majstora, koji je izrađivao kalup ili o pokušaju krivotvorenja.

Sigla:

Materijal: srebro; Orijentacija: 9; Mjere: 15,5 mm; Težina: $0.76 \mathrm{~g}$. Bibliografija: Rengjeo 1959, kat. br. 112 var.; Dolenec 1993., kat. br. 33.

Kralj Stjepan V. Arpadović (1270. - 1272.)

Ban Joakim Pektar (1270. - 1272.)

Kovnica: Zagreb

+MONETA $:$ REGISPS $:$ CLAONI $:$ A $:$

Bilješka:

Av.: Tri sitne točkice ili stilizirana ljiljana između pojedinih slova.

Rv.: Iz središta križa sa svake strane izlazi Ijiljan. U polumjesecu ljiljan. Vrh patibuluma spojen s bisernom kružnicom. Unutar zvijezde na lijevo nedostaje točka. Cirkumfleks iznad sigla.

\section{PN 159_1}

Na reversu zvijezda desno, polumjesec lijevo.

Sigla: Z - R

Materijal: srebro; Orijentacija: 12; Mjere: 16 mm; Težina: $0.70 \mathrm{~g}$.

9. PN 159_2

Sigla: $\mathrm{S}-\mathrm{R}$

Materijal: srebro; Orijentacija: 7; Mjere: 17 mm; Težina: $1.09 \mathrm{~g}$.

10. PN 159_7

Av. MOnETAREGISPSCLAOnA (nedostaje slovo i točkice / ljiljani).

Rv.: točka u zvijezdi; kružić u polumjesecu.

Sigla: S - R

Materijal: srebro; Orijentacija: 4; Mjere: 15 mm; Težina: 0.91 g.

11. PN 159_8

Sigla: $\mathrm{S}-\mathrm{R}$

Materijal: srebro; Orijentacija: 6; Mjere: 16,5 mm; Težina: 0.75 g.

\section{PN 159_10}

Av. Natpis bez točkica (ljiljana)

Sigla: $\mathrm{S}-\mathrm{R}$

Materijal: srebro; Orijentacija: 11; Mjere: 16,5 mm; Težina: $1.02 \mathrm{~g}$.
Due to unskilled production and significant changes in execution, especially on the reverse, it is possible that this was made by another craftsman making the coin die, or this was an attempt at counterfeiting.

Siglum:

Material: silver; Axial orientation: 9; Dimensions: $15.5 \mathrm{~mm}$; Weight: $0.76 \mathrm{~g}$

Bibliography: Rengjeo 1959, cat. no. 112 var.; Dolenec 1993, cat. no. 33 .

\section{King Stephen V of Hungary (1270 - 1272)}

Ban Joachim Gutkeled (1270-1272)

Mint: Zagreb

+MONETA $\because$ REGISPS $\because$ CLAOnI $\because A \cdot$

Note:

OBV: Three small dots or stylized lilies between certain letters.

REV: Lily comes out of the centre of the cross on each side. Lily in crescent moon. Top of patibulum is linked with pearl circle Dot missing within the star on the left. Circumflex above siglum.

8. SF 159_1

On the reverse, star is on the right, crescent moon on the left.

Siglum: २-R

Material: silver; Axial orientation: 12; Dimensions: $16 \mathrm{~mm}$; Weight: $0.70 \mathrm{~g}$

9. SF 159_2

Siglum: S - R

Material: silver; Axial orientation: 7; Dimensions: $17 \mathrm{~mm}$; Weight: $1.09 \mathrm{~g}$.

\section{SF 159_7}

OBV: MOnETAREGISPSCLAOnA (a letter and dots/lilies are missing).

REV: dot in star; circle in crescent moon.

Siglum: S - R

Material: silver; Axial orientation: 4; Dimensions: 15 mm; Weight: $0.91 \mathrm{~g}$.

11. SF 159_8

Siglum: $\mathrm{S}-\mathrm{R}$

Material: silver; Axial orientation: 6; Dimensions: $16.5 \mathrm{~mm}$; Weight: $0.75 \mathrm{~g}$.

12. SF 159_10

OBV: Inscription without dots (lilies)

Siglum: S - R

Material: silver; Axial orientation: 11; Dimensions: $16.5 \mathrm{~mm}$; Weight: $1.02 \mathrm{~g}$. 
13. PN 159_11

Av. MOnETAREGISPSCLAOnA (nedostaje slovo i točkice / ljiljani)

Rv.: točka u zvijezdi; kružić u polumjesecu.

Sigla:S - R

Materijal: srebro; Orijentacija: 10; Mjere: 16 mm; Težina: $0.89 \mathrm{~g}$.

Bibliografija: Rengjeo 1959, kat. br. 130 var., 132 var.; Dolenec 1993., kat. br. 33 var.

Kralj Ladislav IV. (1272. - 1290.)

Različiti banovi (1280. - 1282.)

Kovnica: Zagreb

+MOnETAREGISPSCLOnIA

Bilješka:

Av.: Nedostaje slovo u natpisu.

Rv.: Iz središta križa sa svake strane izlazi ljiljan. U polumjesecu kružić ili ljiljan. Vrh patibuluma spojen s bisernom kružnicom. Unutar zvijezde na lijevo nedostaje točka. Cirkumfleks iznad sigla.

14. PN 159_12

Rv.: U polumjesecu kružić.

Sigla: S - L

Materijal: srebro; Orijentacija: 10; Mjere: 15; 15 X 15,5 mm; Težina: $0.79 \mathrm{~g}$.

15. PN 159_13

Rv.: U polumjesecu Ijiljan.

Sigla: S - L

Materijal: srebro; Orijentacija: 2; Mjere: 15; 15,5 X 15 mm; Težina: $0.45 \mathrm{~g}$.

Bibliografija: Dolenec 1993., kat. br. 38 var.

\section{UGARSKI DENARI}

\section{Kralj Stjepan V. (1270. - 1272.)}

Kovnica: nepoznata

*S*/TEPh/ANRE $/{ }^{*}$ *

16. PN 159_16

Sigla: $M-*$

Materijal: srebro; Orijentacija: 3; Mjere: 13 mm; Težina: 0.59 g.

\section{PN 159_17}

Sigla: $M-*$

Materijal: srebro; Orijentacija: 12; Mjere: $13 \mathrm{~mm}$; Težina: $0.58 \mathrm{~g}$.
13. SF 159_11

OBV: MOnETAREGISPSCLAOnA (letter and dots/lilies missing). REV: dot in star; circle in crescent moon.

Siglum: S-R

Material: silver; Axial orientation: 10; Dimensions: $16 \mathrm{~mm}$; Weight: $0.89 \mathrm{~g}$.

Bibliography: Rengjeo 1959, cat. nos 130 var., 132 var.; Dolenec 1993, cat. no. 33 var.

King Ladislaus IV (1272-1290)

Various bans (1280 - 1282)

Mint: Zagreb

+MOnETAREGISPSCLOnIA

Note:

OBV: A letter in the inscription missing.

REV: Lily comes out of the centre of the cross on each side. Circle or lily in crescent moon. Top of patibulum is linked with pearl circle. Dot missing within the star on the left. Circumflex above the siglum.

14. SF 159_12

REV: Circle in crescent moon.

Siglum: S - L

Material: silver; Axial orientation: 10; Dimensions: 15; $15 \times 15.5$ mm; Weight: $0.79 \mathrm{~g}$.

15. SF 159_13

REV: Lily in crescent moon.

Siglum: S - L

Material: silver; Axial orientation: 2; Dimensions: 15; $15.5 \times 15$ mm; Weight: $0.45 \mathrm{~g}$.

Bibliography: Dolenec 1993, cat. no. 38 var.

\section{HUNGARIAN DENARS}

King Stephen V (1270 - 1272)

Mint: unknown

${ }^{*} \mathrm{~S} * / \mathrm{TEPh} / \mathrm{ANRE} /{ }^{*} \mathrm{X}^{*}$

16. SF 159_16

Siglum: $M-*$

Material: silver; Axial orientation: 3; Dimensions: 13 mm; Weight: $0.59 \mathrm{~g}$.

\section{SF 159_17}

Siglum: $\mathrm{M}$ - *

Material: silver; Axial orientation: 12; Dimensions: $13 \mathrm{~mm}$; Weight: $0.58 \mathrm{~g}$. 
18. PN 159_18

Av.: Umjesto peterolisnih rozeta, slova odvojena šestokrakim zvijezdama.

Sigla: $M-*$

Materijal: srebro; Orijentacija: 5; Mjere: 13 mm; Težina: 0.45 g.

19. PN 159_19

Sigla: $\mathrm{M}-*$

Materijal: srebro; Orijentacija: 11; Mjere: 13 mm; Težina: 0.63 g

20. PN 159_20

Sigla: $M-*$

Materijal: srebro; Orijentacija: 9; Mjere: 13 mm; Težina: 0.44 g

21. PN 159_21

Sigla: $\mathrm{M}-*$

Materijal: srebro; Orijentacija: 9; Mjere: 13 mm; Težina: $0.51 \mathrm{~g}$.

Bibliografija: Rethy 1899, kat. br. 285; Huszar 1979, kat. br. 343;

Unger 1997, kat. br. 257; Gyöngyössy, Winter 2007, kat. br. 495.
18. SF 159_18

OBV: Letters are separated by six-point stars, instead of fiveleaf rosettes.

Siglum: $M-*$

Material: silver; Axial orientation: 5; Dimensions: 13 mm; Weight: $0.45 \mathrm{~g}$.

19. SF 159_19

Siglum: $M-*$

Material: silver; Axial orientation: $11^{\text {h}}$; Dimensions: $13 \mathrm{~mm}$; Weight: $0.63 \mathrm{~g}$

20. SF 159_20

Siglum: $M-*$

Material: silver; Axial orientation: 9; Dimensions: 13 mm; Weight: $0.44 \mathrm{~g}$.

21. SF 159_21

Siglum: $M-*$

Material: silver; Axial orientation: 9; Dimensions: 13 mm; Weight: $0.51 \mathrm{~g}$.

Bibliography: Réthy 1899, cat. no. 285; Huszár 1979, cat. no. 343; Unger 1997, cat. no. 257; Gyöngyössy, Winter 2007, cat. no. 495. 


\section{BIBLIOGRAFIJA BIBLIOGRAPHY}

Bekić 2011 - L. Bekić, Vrećica sa srebrnim novcem iz groblja na trgu Pul Vele crikve u Rijeci, Acta Numismatica, Zbornik radova 6. međunarodnog numizmatičkog kongresa u Hrvatskoj, Zadar 2010, Numizmatički studio Dobrinić \& Dobrinić, 2011, 15-27.

Benažić 2001 - A. Benažić, Podrijetlo simbola kune na hrvatskom novcu, Numizmatičke vijesti 54, 2001, 74-109.

Buturac 1984 - J. Buturac, Popis župa Zagrebačke biskupije 1334. i 1501. godine, Starine JAZU, knjiga 59, Jugoslavenska akademija znanosti i umjetnosti, 1984, 43-108

Demo 1984 - Ž. Demo, Castrum Keukaproncha/Kuwar - Počeci istraživanja: studije iz arheološke i povijesne građe, Podravski zbornik 10, 1984, 320-360.

Demo 2007 - Ž. Demo, Opatovina, tragovi povijesti izgubljeni u sadašnjosti, Arheološki muzej u Zagrebu, 2007

Demo 2013 - Ž. Demo, Nekoliko misli i opažanja o pogrebnim običajima i pokapanju na groblju Drinovci-Greblje, in Kapetanović, V. (ed.), Kultovi mitovi i vjerovanja u Zagori, Zbornik radova sa znanstvenog skupa održanog 14. prosinca 2012. u Unešiću, Kulturni sabor Zagore, Filozofski fakultet u Splitu - Odsjek za povijest, Veleučilište u Šibeniku, 2013, 109-124

Dobrinić 1993 - J. Dobrinić, Prvi hrvatski frizatik hercega Andrije: jedna neobjavljena varijanta, Numizmatičke vijesti 46, 1993, 53-55

Dolenec 1993 - I. Dolenec, Hrvatska numizmatika od početaka do danas, Prvi hrvatski bankovni muzej Privredne banke Zagreb, 1993.

Đaković 1987 - B. Đaković, Novac - Popudbina u posmrtnom ritualu, Etnološka tribina 10, 1987, 51-59.

Filipec 2012 - K. Filipec, Srednjovjekovno groblje i naselje Đakovo - Župna crkva, Istraživanja Katedre za opću srednjovjekovnu i nacionalnu arheologiju Monografije 1, Centar za ranosrednjovjekovna istraživanja Zagreb-Lobor, Odsjek za arheologiju Filozofskog fakulteta Sveučilišta u Zagrebu, 2012

Gilchrist 2008 - R. Gilchrist, Magic for the Dead? The Archaeology of Magic in Later Medieval Burials, Medieval Archaeology 52, 2008, 119-159.

Gyöngyössy 2015/2 - M. Gyöngyössy, 13. századi esztergomi és budai kamaraispánok, Az Érem 71, 2015/2, 1-17.

Gyöngyössy, Winter 2007 - M. Gyöngyössy, H. Winter, Münzen und Medaillen des ungarischen Mittelalters, 1000-1526, Sammlungskataloge des Kunsthistorischen Museums 4, Kunsthistorisches Museum, 2007.

HAZU Archive - Croatian Academy of Sciences and Arts: P. Ritter Vitezović, Banologija seu de banatu Chroatiae, script written around 1710

Herman Kaurić 2006 - V. Herman Kaurić, Srednjovjekovni Pakrac i njegovi banovci, Zbornik povijesnog društva Pakrac - Lipik 3, 2006, 10-21.

Huszár 1979 - L. Huszár, Münzkatalog Ungarn von 1000 bis heute, Corvina, 1979.

Kampuš 1981 - I. Kampuš, Zagrebački Gradec u XIII i XIV st. Prilog društvenom i privrednom razvoju, in Kampuš, I., Mirnik, I. (eds.), Zagrebački novac i medalje, Arheološki muzej u Zagrebu, Muzej grada Zagreba, Hrvatsko numizmatičko društvo, 1981, 3-13.

Kampuš 1982 - I. Kampuš, Zagrebački Gradec u XIII i XIV st. Prilog društvenom i privrednom razvoju, Obo/ 34, 1982, 8-14.

Klaić 1904 - V. Klaić, Marturina. Slavonska daća u srednjem vijeku, Rad Jugoslavenske akademije znanosti i umjetnosti 157, 1904, 114- 213.

Korčmaroš 1998 - L. Korčmaroš, Kratak pregled historiografije slavonskih banovaca, in Dobrinić, J. (ed.), Zbornik radova 2. međunarodnog numizmatičkog kongresa u Hrvatskoj / Proceedings of the 2th International Numismatic Con gress in Croatia, Numizmatički studio Dobrinić \& Dobrinić, 1998, 89-97.

Králíková 2007 - M. Králíková, Panoráma antropologie biologické - sociální kulturní, Pohřební ritus 16.-18. století na území střední Evropy (antropologicko-archeologická studie), Modulové učební texty pro studenty antropologie a př́buzných oborů“ 35, Nadace Universitas v Brnĕ, Akademické nakladatelstvi CERM, 2007.

Križan 2010 - B. Križan, Kovnica je bila u Pakracu, Zbornik povijesnog društva Pakrac - Lipik 7, 2010, 5-18

Krznar 2013 - S. Krznar, Arheološko istraživanje lokaliteta Torčec - Cirkvišče 2012. godine, Annales Instituti Archaeologici 9, 2013, 64-68

Krznar 2014 - S. Krznar, Je li postojao običaj polaganja novca u kasnosrednjovjekovne/ranonovovjekovne grobove na prostoru sjeverne Hrvatske?, Starohrvatska prosvjeta 41, 2014, 225-230

Lorenzo 2008 - C. V. Lorenzo, Funerary traditions and death worship in the church of the Borgia in Gandia: interpretations from archaeology, World Archaeology 40/3, 407-426.

Mašić, Pantlik 2008 - B. Mašić, B. Pantlik, 0 nalazu novca iz groba 74 u Parku Grič na zagrebačkom Gornjem gradu, Vjesnik Arheološkog muzeja u Zagrebu 41, 2008, 331-342.

Metcalf 1965 - D. M. Metcalf, Coinage in the Balkans 820-1355, Institute for Bal kan Studies, 1965.

Mirnik 1984 - I. Mirnik, Novac akvilejskih patrijarha iz Vukovara i opticaj akvilejskih denara u našim krajevima, in Majnarić-Pandžić, N. (ed.), Izdanja Hrvatskog arheološkog društva (Arheološka istraživanja u istočnoj Slavoniji i Baranji) 9, 1984, 223-233.

Mirnik 1994 - I. Mirnik, Skupni nalaz novca iz Hrvatske X. Skupni nalaz akvilejskih denara 15. st. iz Vukovara, Vjesnik Arheološkog muzeja u Zagrebu 26-27, 1993-1994, 85-123.

Mirnik 2004 - I. Mirnik, Novac iz starohrvatskih grobova, Vjesnik Arheološkog muzeja u Zagrebu 37, 2004, 205-250.

Mirnik 2008 - I. Mirnik, Najsitnija kulturna dobra. Novac i njegova uloga u Srednjovjekovnoj Hrvatskoj i Slavoniji, Crkvena kulturna dobra Analecta 6, 2008, 125-143.

Rengjeo 1959 - I. Rengjeo, Corpus der mittelalterlichen Münzen von Kroatien, Slavonien, Dalmatien und Bosnien, Akademische Druck- und Verlagsanstalt, 1959

Réthy 1899 - L. Réthy, Corpus Nummorum Hungariae 1, Magyar Tudományos Akadémia, 1899

Ruttkay 1989 - A. Ruttkay, Prvky gotickej módy v odeve a ozdobách dedinského obyvatel'stva na územi Slovenska, Archaeologia historica 16, 1989, 355-378.

Sekelj Ivančan 2008 - T. Sekelj Ivančan, Župna crkva ... sancti Stephanis regis circa Drauam - prilog tumačenju širenja ugarskoga političkog utjecaja južno od Drave / The parish church ... sancti Stephanis regis circa Drauam - a contribution to the interpretation of the spread of Hungarian political influence south of the Drava, Prilozi Instituta za arheologiju u Zagrebu 25, 2008, 97-118.

Sekelj Ivančan 2010 - T. Sekelj Ivančan, Podravina u ranom srednjem vijeku, Monografije Instituta za arheologiju 2, Institut za arheologiju, 2010.

Sekelj Ivančan, Tkalčec 2003 - T. Sekelj Ivančan, T. Tkalčec, Arheološko nalazište Torčec - Cirkvišče, Podravina 2/4, 2003, 5-36

Smajlagić 2013 - R. Smajlagić, Neke tipološke oznake na slavonskim banskim denarima kovanim za Stjepana V. (1270.-1272.), Numizmatičke vijesti 66, 2013, 38-43.

Székely 1980 - G. V. Székely, Slawonische Banalmünzprägung, Dissertationes Archaeologicae 2/8, Institutum Archaeologicum Universitatis de Rolando Eötvös nominatae, 1980

Šlaus et al. 2015 - M. Šlaus, V. Vyroubal, ž. Bedić, J. Perić Peručić, Rezultati an tropološke analize ljudskog osteološkog materijala s nalazišta Torčec - Cirkvišće, unpublished report EP - $248-11 / 15$, Antropološki centar Hrvatske akademije znanosti i umjetnosti, 2015 . 
Štefan 2019 - L. Štefan, Moneta regis pro Sclavonia from the Mekiš-Zgruti hoard, Vjesnik Arheološkog muzeja u Zagrebu 52, 2019, 179-212.

Tkalčec 2011 - T. Tkalčec, Arheološka istraživanja nalazišta Crkvari - crkva Sv. Lovre 2010. godine, Annales Instituti Archaeologici 8, 2011, 23-28.

Tomičić 2019 - Ž. Tomičić, Bjelobrdski kulturni krug - Groblja 9. do 13. stoljeća u međurječju Mure, Drave, Dunava i Save, Hrvatska akademija znanosti i umjetnosti, 2019.

Truhelka 1897 - Ć. Truhelka, Slavonski banovci: prinos hrvatskoj numismatici, Zemaljska štamparija, 1897
Unger 1997 - E. Unger, Magyar éremhatározó I (1000-1540), Ajtósi Dürer Könyvkiadó, 1997

Vučić 2006 - J. Vučić, Nalazi grobova u crkvi sv. Martina kod Sukošana, Starohrvatska prosvjeta 33, 2006, 213-242.

Wyroubal 1981 - Z. Wyroubal, Nešto malo o našim banovcima, Obol 33, 1981, 8-10. 

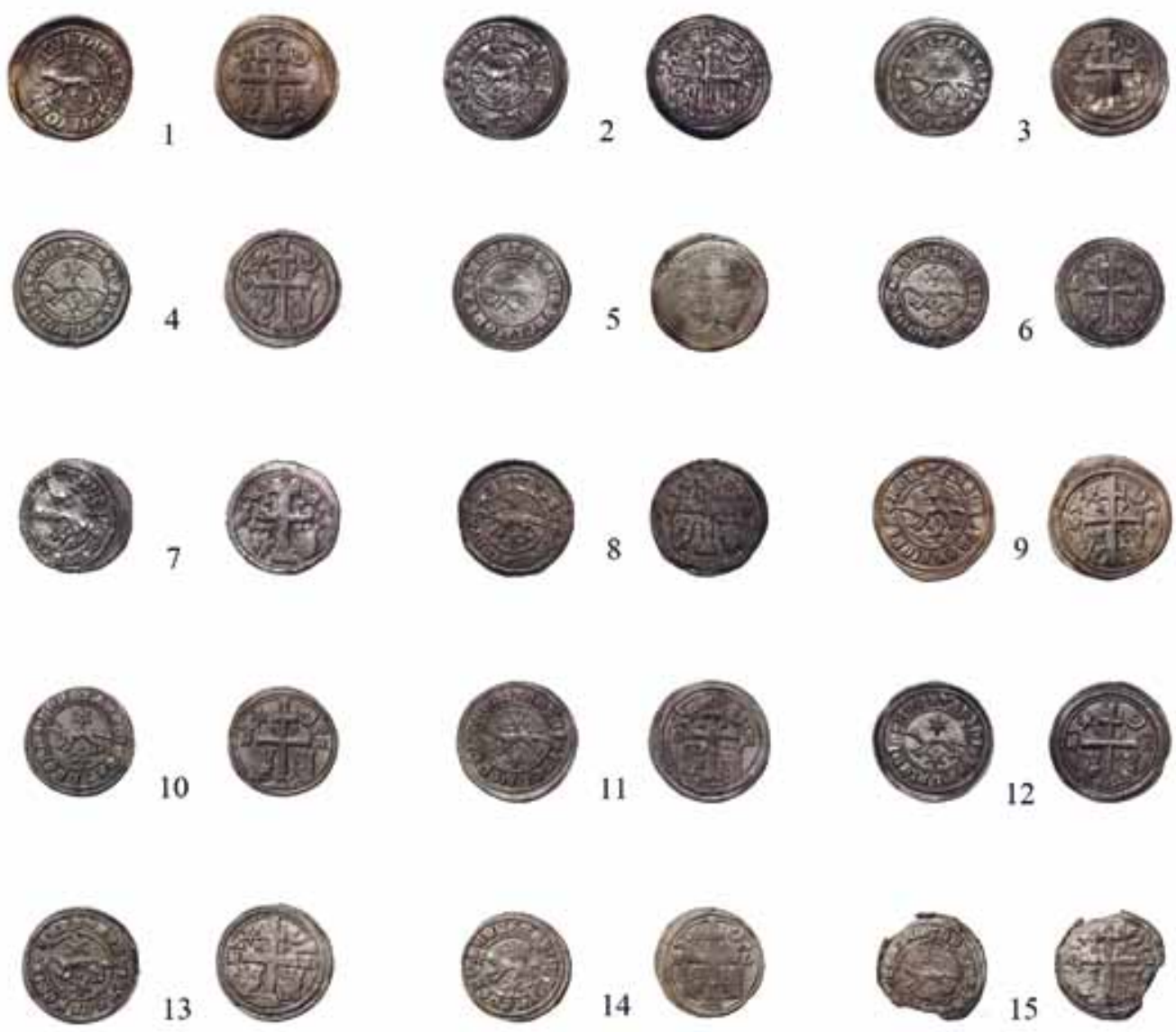

15
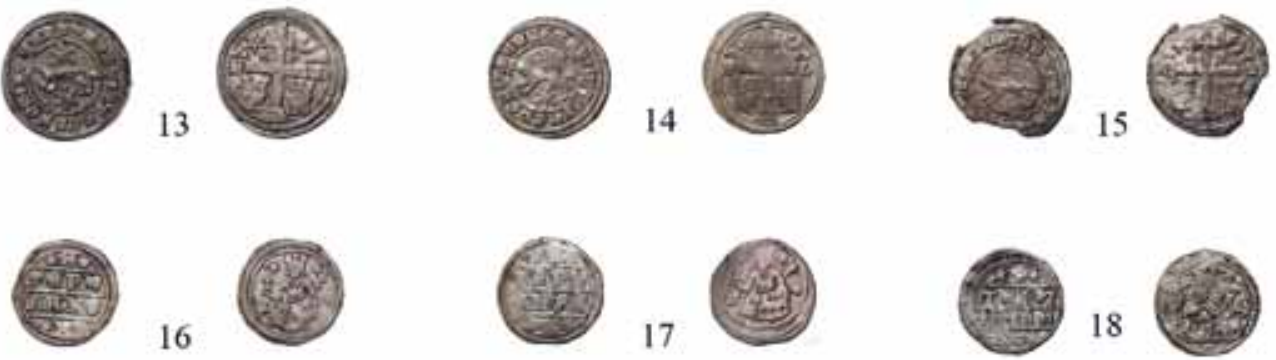

18
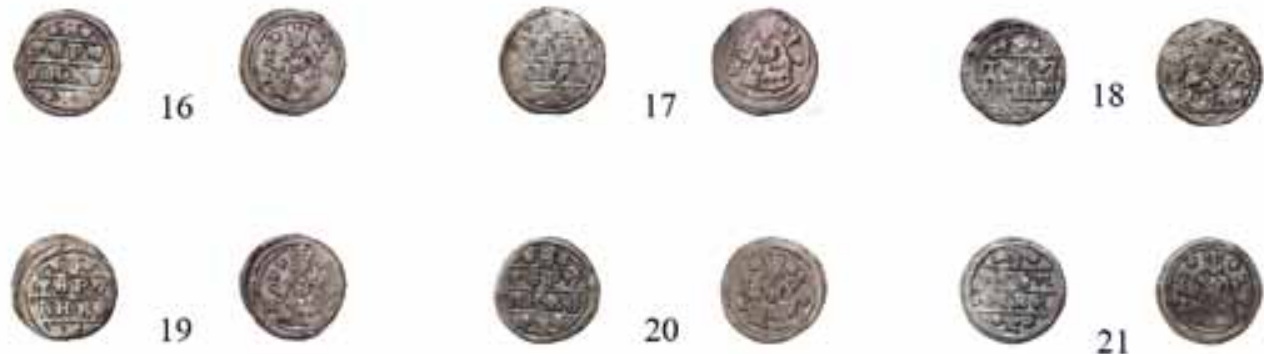

20
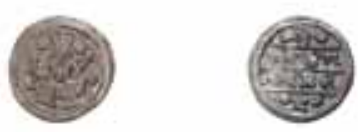

21
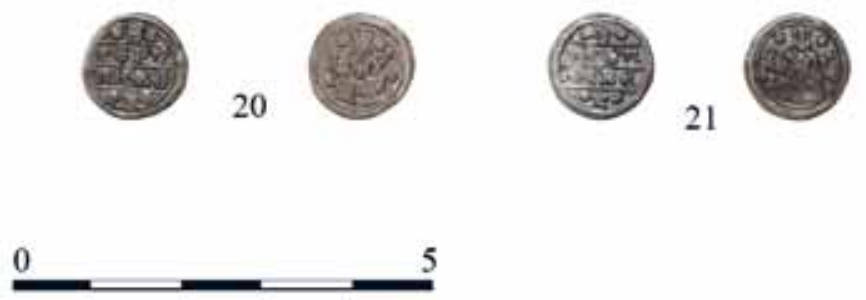

TABLA 1.

Banski i ugarski denari iz groba 241 (izradio L. Štefan).
PLATE 1.

Denarii banales and Hungarian denars from grave 241 (made by L. Štefan). 